\title{
CALIBRATION OF METHODS FOR DESIGNING LARGE-DIAMETER BORED PILES: SERVICEABILITY LIMIT STATE
}

\author{
L. M. ZHANG ${ }^{\mathrm{i})}$ and L. F. CHU ${ }^{\mathrm{ii})}$
}

\begin{abstract}
Limit-state design methodologies for serviceability of foundations are an important area under development. Due to various sources of uncertainty, settlement analysis models and the soil or rock properties required for settlement analysis may be in error; hence any settlement estimate is a random variable. To develop limit-state design codes for largediameter bored piles, analysis methods for estimating the settlement of large-diameter bored piles need to be carefully calibrated. This paper aims at calibrating four analysis methods for bored piles in soils (Vesic's elastic method, Mayne and Harris's analytical solution, O'Neill and Reese's load-transfer method, and a method based on load-transfer curves established in this paper based on Hong Kong data) and three methods for bored piles socketed in rocks (Vesic's method, Kulhawy and Carter's method, and a load-transfer method using the correlations established in this paper based on Hong Kong data). For rock-socketed piles, two methods for estimating the rock deformation modulus are further studied: One based on a correlation with rock quality designation and the other based on a correlation with rock mass rating. These analysis models have been calibrated at the working load level using 36 cases of static loading tests on large-diameter bored piles in Hong Kong with complete soil and rock information. The effects of construction on pile settlement have also been included.
\end{abstract}

Key words: bored piles, limit state design, piles, reliability, serviceability, uncertainty (IGC: E2)

\section{INTRODUCTION}

Limit-state design methodologies for serviceability of foundations are an important area under development. The philosophy behind the limit state design deliberates different performance criteria and manages the potential engineering risk explicitly. Ideally, uncertainties encountered in design for the serviceability limit states (SLS) should be accommodated using reliability principles in a similar way for the uncertainties encountered in the design for the ultimate limit states (ULS).

The performance function for SLS can be expressed as;

$$
g=S_{\mathrm{t}}-S_{\mathrm{ef}}
$$

where $S_{\text {ef }}=$ estimated foundation system settlement under the serviceability load combination and $S_{\mathrm{t}}=$ limiting tolerable settlement of the superstructure. Due to various sources of uncertainty in subsurface conditions, construction effects, load effects, errors in obtaining soil or rock properties, and errors of settlement analysis models, any settlement estimate is a random variable. To develop limit-state design codes for large-diameter bored piles, analysis methods for estimating the settlement of largediameter bored piles need to be carefully calibrated. This paper aims at calibrating the performance of four analy- sis methods for bored piles in soils and three methods for bored piles socketed in rocks which include: An elastic method suggested by Vesic (1977), analytical solutions derived by Mayne and Harris (1993) and Kulhawy and Carter (1992), the load-transfer method proposed by Reese and O'Neill (1989) and O'Neill and Reese (1999), and methods based on load-transfer curves established in this paper based on a Hong Kong bored pile database (Chu, 2007). For rock-socketed piles, two methods for estimating the rock deformation modulus are further examined: One based on correlations with the rock quality designation (RQD) and the other based on correlations with the rock mass rating (RMR). The reliability of each analysis method is indicated by a model bias factor and a serviceability reliability index.

\section{DATABASE}

Information of 62 static loading tests on large-diameter bored piles and barrettes in Hong Kong, in which 56 were instrumented, was compiled in a database. Details of the database have been reported by Chu (2007). Pile dimensions, construction details, and ground conditions are first gathered for the database. Parameters related to strength and deformability of soil or rock are also

i) Associate Professor, Department of Civil and Environmental Enginneering, the Hong Kong University of Science and Technology, Hong Kong (cezhangl@ust.hk).

i) Research Assistant, ditto.

The manuscript for this paper was received for review on January 10, 2008; approved on March 26, 2009.

Written discussions on this paper should be submitted before July 1, 2010 to the Japanese Geotechnical Society, 4-38-2, Sengoku, Bunkyo-ku, Tokyo 112-0011, Japan. Upon request the closing date may be extended one month. 
gathered. For the piles in soils, the uncorrected standard penetration test $(\bar{N})$ is commonly used to represent the soil shear strength. Therefore, $\bar{N}$ values for all soil layers are obtained. For piles on rocks, information of the weathering degree, average unconfined compressive strength (UCS), total core recovery (TCR), rock quality designation (RQD), and rock mass rating (RMR) of the bedrock is collected, if available. For the purpose of calibrating settlement analysis models, the load-settlement curves from 34 static loading tests with complete soil and rock information are utilized. Among these test piles, 20 piles were founded in soils and 14 piles were socketed in rocks. In addition results of static loading tests on instrumented piles, such as load distribution along depth and pile shaft or pile toe load-transfer curves, are also available for settlement analysis.

\section{DESIGN METHODS UNDER CALIBRATION}

In this study, several common settlement analysis methods are calibrated. Detailed formulations for these analysis methods for piles in soils and piles socketed in rocks are summarized in Tables 1 and 2, respectively.

\section{Vesic's Method (1977)}

Vesic (1977) suggested a semi-empirical elastic method to calculate the settlement of single piles in the working load range. The total settlement consists of three components: Elastic compression of the pile $\left(w_{\mathrm{c}}\right)$, settlement of the pile base due to the load transferred to the soil along the pile shaft $\left(w_{\mathrm{bs}}\right)$, and settlement of the pile base due to the load transferred to the base $\left(w_{\mathrm{bb}}\right)$.

The elastic pile compression can be calculated given the

Table 1. Design methods for piles in soils

\begin{tabular}{|c|c|}
\hline Design method & Detailed formulations \\
\hline $\begin{array}{l}\text { Vesic (1977) } \\
\text { [Method 1-Soil] }\end{array}$ & $\begin{array}{l}Q_{\mathrm{ms}}=\text { shaft resistance of pile }(\mathrm{kN}) \\
Q_{\mathrm{mb}}=\text { toe resistance of pile }(\mathrm{kN}) \\
q_{\mathrm{max}}=\text { unit ultimate toe resistance }(\mathrm{kPa}) \\
C_{\mathrm{p}}=\text { dimensionless empirical coefficient } \\
\left(C_{\mathrm{p}}=0.09-0.18 \text { for sand; } 0.03-0.06 \text { for clay; and } 0.09-0.12 \text { for silt }\right)\end{array}$ \\
\hline $\begin{array}{l}\text { Analytical solution } \\
\text { (Mayne and Harris, 1993) } \\
\text { [Method 2-Soil] }\end{array}$ & 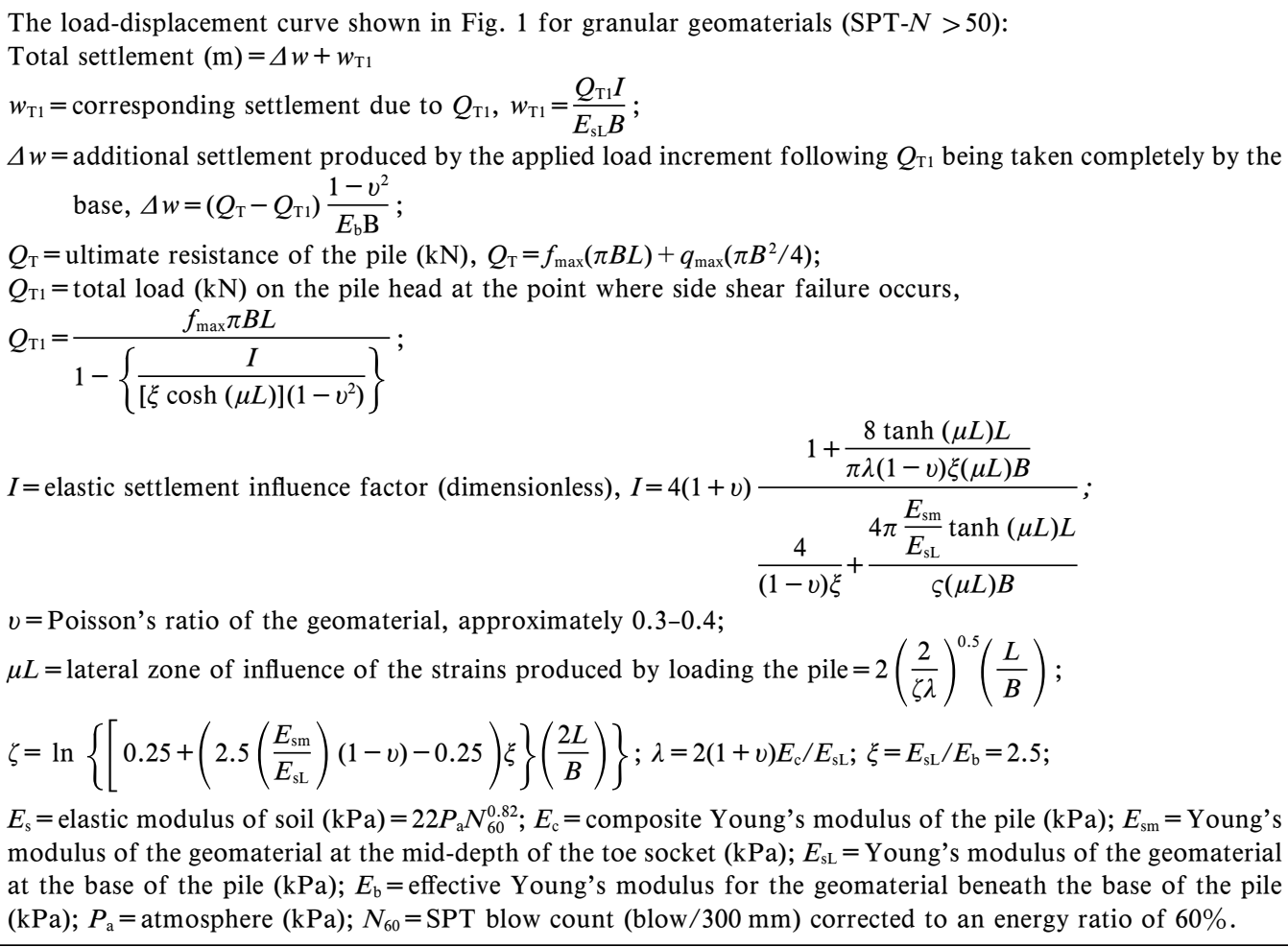 \\
\hline $\begin{array}{l}\text { Load transfer method } \\
\text { (Reese and O’Neill, 1989) } \\
\text { [Method 3-Soil] }\end{array}$ & Load transfer curves are shown in Figs. 2-4. \\
\hline $\begin{array}{l}\text { Load transfer method } \\
\text { (Hong Kong data) } \\
\text { [Method 4-Soil] }\end{array}$ & Formulations for the load transfer curves are shown in Figs. 2-4. \\
\hline
\end{tabular}


Table 2. Design methods for piles socketed in rocks

\begin{tabular}{|c|c|}
\hline Design method & Detailed formulations \\
\hline $\begin{array}{l}\text { Vesic (1977) } \\
\text { [Method 1-Rocks] }\end{array}$ & $\begin{array}{l}w_{\mathrm{T}}=w_{\mathrm{c}}+w_{\mathrm{bb}}+w_{\mathrm{bs}} \\
\text { where } w_{\mathrm{c}}=\text { elastic compression of the pile; } w_{\mathrm{bs}}=\frac{\bar{f}_{\mathrm{s}} B}{E_{\mathrm{B}}^{*}} I_{\mathrm{ps}} ; w_{\mathrm{bb}}=\frac{q_{\mathrm{p}} B}{E_{\mathrm{S}}^{*}} I_{\mathrm{pp}} ; E_{\mathrm{s}}^{*}=\frac{E_{\mathrm{s}}}{1-v_{\mathrm{s}}^{2}} ; \\
I_{\mathrm{ps}}=2+0.35 \sqrt{D / B} ; B=\text { pile diameter }(\mathrm{m}) ; D=\text { pile embedded length }(\mathrm{m}) ; \bar{f}_{\mathrm{s}}=\text { average unit shear transmitted } \\
\text { across the pile shaft }(\mathrm{kPa}) ; q_{\mathrm{p}}=\text { net pressure on the toe }(\mathrm{kPa}) ; E_{\mathrm{B}}^{*}, E_{\mathrm{s}}^{*}=\text { plane-strain modulus of deformation } \\
(\mathrm{kPa}) ; E_{\mathrm{s}}=\text { modulus of deformation }(\mathrm{kPa}) ; I_{\mathrm{pp}}, I_{\mathrm{ps}}=\text { dimensionless influence factors. }\end{array}$ \\
\hline $\begin{array}{l}\text { Analytical solution } \\
\text { (Kulhawy and Carter, } \\
\text { 1992) } \\
\text { [Method 2-Rocks] }\end{array}$ & $\begin{array}{l}w_{\mathrm{T}}=w_{\mathrm{T} 1}+\Delta w \\
w_{\mathrm{T} 1} \text { at the end of segment } 1 \text { in Fig. } 1 \text { is calculated using the same formulations in [Method } 2 \text {-Soil], in which } L \text { is } \\
\text { the length of socket }(\mathrm{m}) \text { or the socket penetration }(\mathrm{m}) ; f_{\mathrm{max}} \text { is estimated using the method suggested by O'Neill } \\
\text { and Reese }(1999) ; E_{\mathrm{sL}} \text { is taken as } E_{\mathrm{m}} \text { of the rock mass along the socket; } \xi \text { is taken as } 1.0 ; v \text { is in the range of } 0.25 \text { to } \\
0.35 \text { for most rocks. } \\
w_{\mathrm{T}} \text { at the end of segment } 2 \text { in Fig. } 1 \text { is, } \\
w_{\mathrm{T}}=F_{3}\left(Q_{\mathrm{T}} / \pi E_{\mathrm{m}} B\right)-F_{4} B \\
\text { where; } F_{3}=a_{1}\left(\lambda_{1} B C_{3}-\lambda_{2} B C_{4}\right)-4 a_{3} ; F_{4}=\left[1-a_{1}\left(\frac{\lambda_{1}-\lambda_{2}}{D_{4}-D_{3}}\right) B\right] a_{2}\left(\frac{c}{E_{\mathrm{m}}}\right) ; \\
a_{1}=\left(1+V_{\text {concrete }}\right) \ln \left[5(1-v)\left(\frac{D}{B}\right)\right]+a_{2} ; a_{2}=\left[\left(1-V_{\text {concrete }}\right)\left(\frac{E_{\mathrm{m}}}{E_{\mathrm{c}}}\right)+(1+v)\right]\left(\frac{1}{2 \tan \phi \tan \Psi}\right) ; \\
\lambda_{1}=\left[-\beta+\left(\beta^{2}+4 \alpha\right)^{0.5}\right] / 2 \alpha ; \lambda_{2}=\left[-\beta-\left(\beta^{2}+4 \alpha\right)^{0.5}\right] / 2 \alpha ; \\
\beta=a_{3}\left(\frac{E_{\mathrm{c}}}{E_{\mathrm{m}}}\right) B ; a_{3}=\left(\frac{V_{\text {concrete }}}{2 \tan \Psi}\right)\left(\frac{E_{\mathrm{m}}}{E_{\mathrm{c}}}\right) ; \alpha=a_{1}\left(\frac{E_{\mathrm{c}}}{E_{\mathrm{m}}}\right)\left(\frac{B^{2}}{4}\right) ; C_{3}=\frac{D_{3}}{\left(D_{4}-D_{3}\right.} ; C_{4}=\frac{D_{4}}{\left(D_{4}-D_{3} ;\right.} \\
D_{3}=\left[\pi\left(1-v^{2}\right)\left(\frac{E_{\mathrm{m}}}{E_{\mathrm{b}}}\right)+4 a_{3}+a_{1} \lambda_{2} B\right] \text { exp }\left(\lambda_{2} D\right) ; D_{4}=\left[\pi\left(1-v^{2}\right)\left(\frac{E_{\mathrm{m}}}{E_{\mathrm{b}}}\right)+4 a_{3}+a_{1} \lambda_{1} B\right] \exp \left(\lambda_{1} D\right) ; \\
\frac{R_{\mathrm{B}}(\text { developed })}{Q_{\mathrm{T}}(\text { applied })}=P_{3}+P_{4}\left[\pi B^{2} c / Q_{\mathrm{T}}(\text { applied })\right] ; \\
P_{3}=a_{1}\left(\lambda_{1}-\lambda_{2}\right) B \exp \left[\left(\lambda_{1}-\lambda_{2}\right) / D\right]\left(D_{4}-D_{3}\right) ; \\
P_{4}=a_{2}\left\{\exp \left[\lambda_{2} D\right]-\exp \left[\lambda_{1} D\right]\right\} /\left(D_{4}-D_{3}\right) . \\
\text { These equations are used to describe the load-displacement curve shown in Fig. } 1 .\end{array}$ \\
\hline $\begin{array}{l}\text { Load transfer method } \\
\text { (Hong Kong data) } \\
\text { [Method 3-Rocks] }\end{array}$ & $\begin{array}{l}w_{\mathrm{T}}=w_{\mathrm{c}}+w_{\mathrm{bb}}+w_{\mathrm{bs}}, \text { where } \\
w_{\mathrm{c}}=\text { elastic compression of the pile; } \\
w_{\mathrm{bs}}=\text { settlement of the base due to the load transferred to soil along the pile shaft, represented by the load trans- } \\
\text { fer curve in Fig. } 5 \text {; } \\
w_{\mathrm{bb}}=\text { settlement of the base due to the load transferred to the base (Timoshenko and Goodier, 1970): } \\
\qquad \frac{\pi}{2} P_{\text {end }}\left(1-\mathrm{v}_{\mathrm{r}}^{2}\right) a \\
w_{\mathrm{bb}}=\frac{E_{\mathrm{m}} n}{\text { where } E_{\mathrm{m}} \text { can be expressed as }} \\
\begin{array}{ll}\text { Correlation with RQD (ASTM, 1979) } & \log E_{\mathrm{m}}=0.0205 \mathrm{RQD}(\%)-0.429(\mathrm{GPa}) \\
\text { Correlation with RMR (GEO, 2006) } & E_{\mathrm{m}}=0.06 e^{(0.05 \mathrm{RMR})}(\mathrm{GPa}) \\
\text { Own correlation with RQD } & E_{\mathrm{m}}=0.574 \mathrm{RQD}^{1.947}(\mathrm{MPa})\end{array}\end{array}$ \\
\hline
\end{tabular}

magnitude and distribution of the shaft load. In this study, $14 \%$ and $60 \%$ of the applied load are assumed to be taken by the toe for piles in soils and piles socketed in rocks, respectively based on static loading test results in the database. A parabolic distribution of shaft load is assumed. For the prediction of $w_{\mathrm{bs}}$ and $w_{\mathrm{bb}}$, the soil surrounding the piles is assumed to be elastic and isotropic, and described by a modulus of deformation $\left(E_{\mathrm{s}}\right)$, a planestrain modulus of deformation of the soil below the pile toe $\left(E_{\mathrm{s}}^{*}\right)$, and Poisson's ratio $\left(v_{\mathrm{s}}\right) . E_{\mathrm{s}}$ can be determined by laboratory tests. However, as $E_{\mathrm{s}}$ is highly dependent on the stress level and stress path, it is more economical and reliable to determine $E_{\mathrm{s}}$ using empirical relations with in-situ test results. For piles socketed in rocks, correlative relationships between $E_{\mathrm{s}}$ and RQD or RMR are established in this paper based on information in the database.

For piles in soils, the formulations for $w_{\mathrm{bs}}$ and $w_{\mathrm{bb}}$ are further simplified, which only require the information of pile dimensions, toe load and shaft load, and an empirical coefficient $\left(C_{\mathrm{p}}\right)$ that depends on soil type and method of construction. Suggested values of $C_{\mathrm{p}}$ by Vesic (1977) are shown in Table 1. These values are applicable to conditions where there are no hard layers within ten pile diameters below the pile toe. $C_{\mathrm{p}}$ should be lowered if rock exists within ten pile diameters below the toe. If rock exists at five pile diameters below the toe, $88 \%$ of $C_{\mathrm{p}}$ will remain; if rock exists at one pile diameter below the toe, only $51 \%$ of $C_{\mathrm{p}}$ will be used.

\section{Simplified Closed-form Elastic Solution}

Randolph and Wroth (1978) suggested a simplified closed-form elastic solution for cylindrical piles. Based on the solution, Mayne and Harris (1993) proposed a method for predicting the load-settlement behaviour of piles in soils; and Kulhawy and Carter (1992) formulated the load-settlement behaviour of drilled shaft rock sock- 


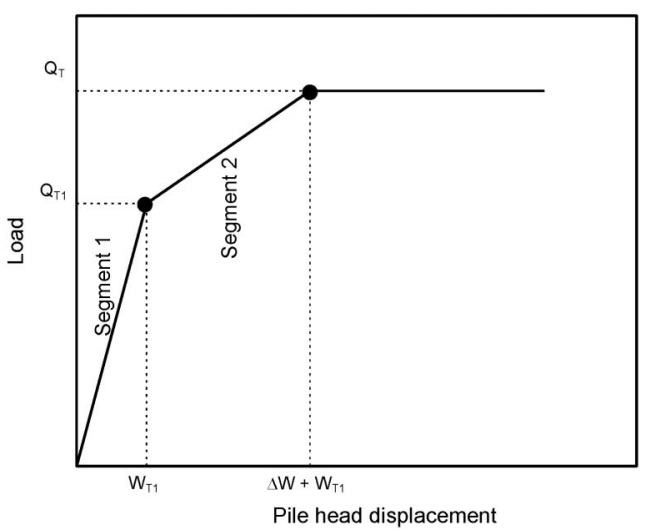

Fig. 1. Load-displacement curve in the analytical solution proposed by Kulhawy and Carter (1992)

ets. In this elastic solution, piles are assumed to be unstressed initially and so the construction effects are not considered.

For piles in soils, only granular materials with SPT $N$ values larger than 50 are considered; in other words, any overburden with SPT $N$ less than 50 is disregarded. The load-settlement relation of a bored pile is simplified into three segments, as shown in Fig. 1. The load and settlement at the first turning point correspond to the condition that causes complete side shear failure. The additional settlement after the first turning point is produced by the continuous increment of applied load which is completely taken by the pile toe. The pile resistance continues to increase until the ultimate toe resistance of the pile is fully mobilized.

For a drilled shaft rock socket, it is assumed that the behaviour of the rock is elastic till the side shear failure occurs instantaneously along the entire rock socket. The toe is assumed to perform elastically till complete failure. The load-settlement behaviour predicted from the solution is only for the rock socket and not for the whole pile. As the elastic pile compression contributes significantly to the total pile settlement, the elastic pile compression should be added to the estimated rock-socket settlement in order to derive the load-settlement relation for the whole pile. The amount of load transferred through the rock socket and the toe has to be assumed. Based on the results of static loading tests in the database, the rock socket and toe take up $70 \%$ to $98 \%$ of the applied load with an average of $85 \%$. Therefore, in this study, three scenarios in which $70 \%, 85 \%$ and $100 \%$ of the applied load are transferred to the rock socket and toe are evaluated.

\section{Reese and O'Neill's Method (1989)}

The load-transfer method gains wide acceptance for settlement prediction because it incorporates non-linear soil behaviour and detailed soil layering (Coyle and Reese, 1966). In addition, some construction effects can be included in the load-transfer method if the load-transfer curves are back calculated from instrumented pile test results (Colye and Reese, 1966; GEO, 2006).
In the load-transfer method, a pile in soil is modelled by discrete elements and the soil resistance is simulated by nonlinear springs. Each spring can be described by a load-transfer curve. The curve can be either derived theoretically or back calculated from results of static loading tests. Back analysis is considered as a viable approach as it can include construction effects implicitly (GEO, 2006). Reese and O'Neill (1989) analyzed the behaviour of a set of single, full-size drilled shafts in soils under compression loading and suggested normalized load-transfer curves for side resistance and toe resistance in cohesionless soils and cohesive soils. As the proposed load-transfer models were derived empirically, which highly depend on the soil and rock properties, the models might be most applicable to similar scenarios where the load-transfer data are extracted. In this paper, in addition to evaluating the applicability of the load-transfer curves suggested by Reese and O'Neill (1989) to Hong Kong cases, the loadtransfer in piles in Hong Kong is also studied independently and load-transfer models for large-diameter bored piles in Hong Kong are suggested.

\section{Load-transfer Method based on Hong Kong Data}

In this study, an effort is made to establish load-transfer curves for predicting settlement of large-diameter bored piles considering likely construction effects. The shaft resistance-local displacement curves and toe resistance-toe displacement curves are interpreted from the results of 13 full-scale static loading tests in Hong Kong. For piles in soils, as different types of soil exhibit different engineering behaviour, the shaft resistance-local displacement curves are studied separately for several types of soil (e.g., fill, alluvium, decomposed volcanics, and decomposed granitic soils). The use of permanent liner and shaft grouting can affect the interaction between the pile and the surrounding soil; therefore, the loadtransfer curves for the piles involving the two special construction methods are further studied. A more detailed description of construction effects has been presented by Chu (2007).

Larger movements are required to fully mobilize the pile toe resistance (GEO, 2006). However, the toe resistance in soil was not fully mobilized in most of the load tests. A method was then applied to extrapolate the original load-settlement curve to a toe displacement of $5 \%$ of the pile diameter $(B)$, assuming an exponential function $y=a x^{b}$ where $a$ and $b$ are two fitting coefficients. The displacement of $5 \% B$ is considered sufficient to mobilize the toe resistance (Reese and O'Neill, 1989).

The mobilized shaft or toe resistance in the load-transfer curves is normalized by its ultimate resistance and the local displacement is normalized by the pile diameter. Figures 2(a)-(d) show the normalized shaft resistancedisplacement curves for piles founded in four different types of soil; Fig. 3 shows the normalized shaft resistance-displacement curves for piles with shaft grouting; and Fig. 4 shows the normalized toe load transfer curves. The normalized curves for each case generally fall into a narrow range, and a logarithmic function is used to fit the 

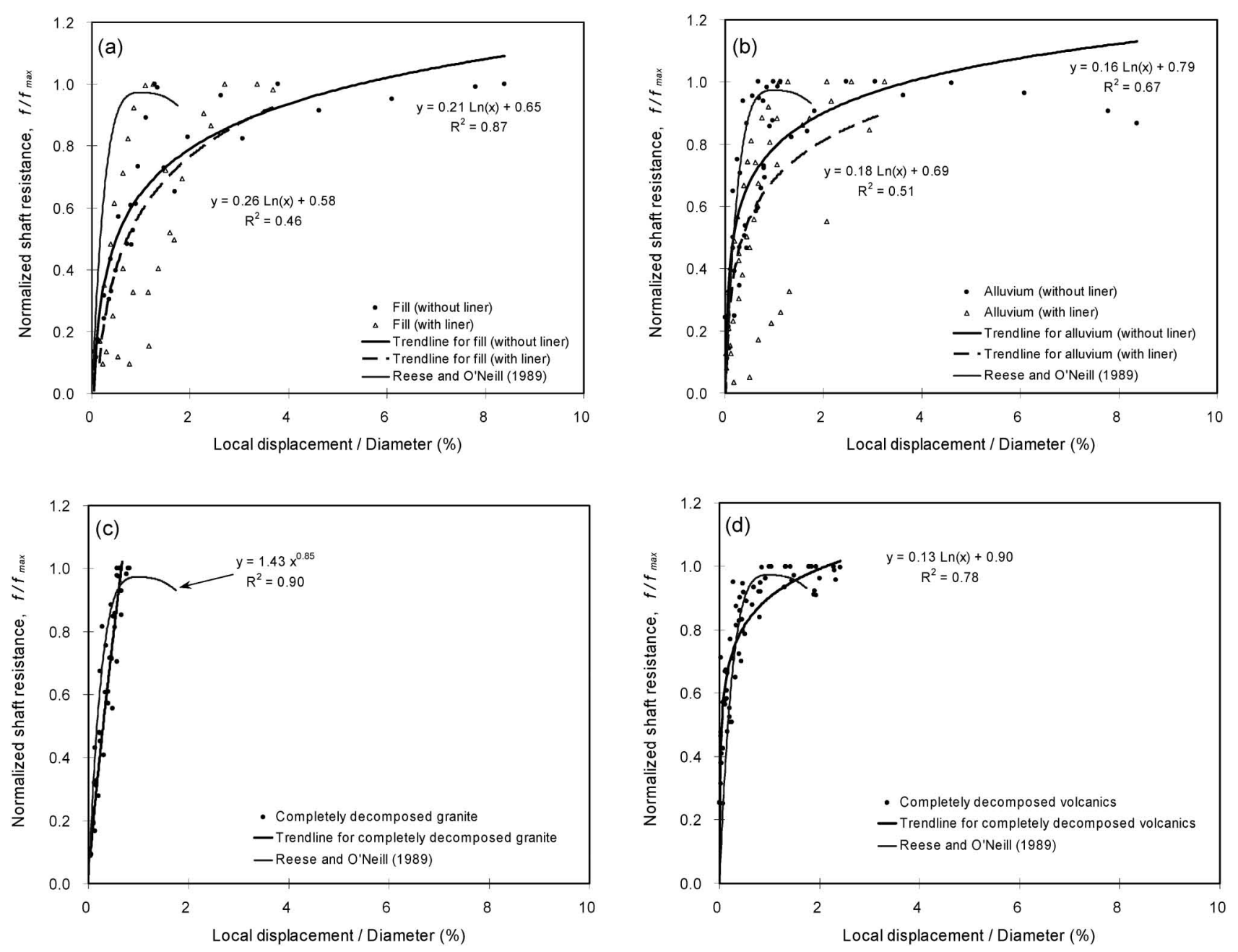

Fig. 2. Shaft load-transfer curves for piles in (a) fill, (b) alluvium, (c) completely decomposed granite and (d) completely decomposed volcanics

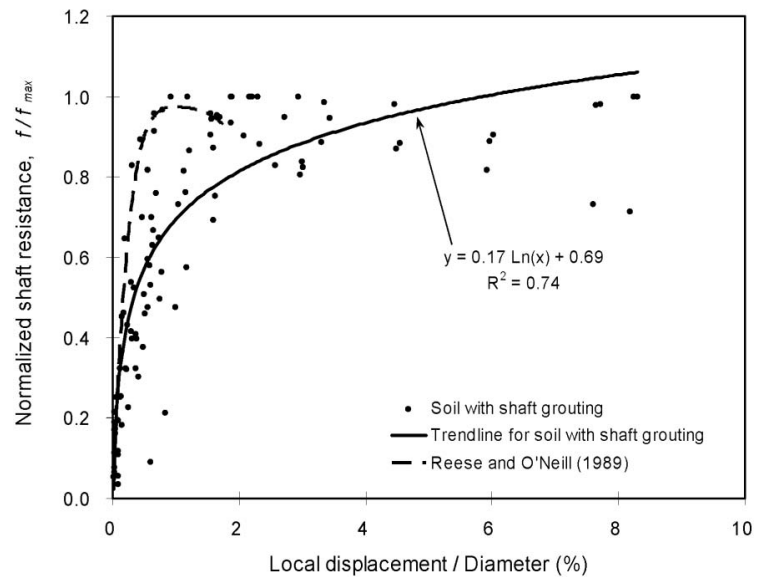

Fig. 3. Shaft load-transfer curves for piles in soils with shaft grouting

trendline. These trendlines are also shown in Figs. 2-4 and compared with the normalized load-transfer curves suggested by Reese and O’Neill (1989).

For piles socketed in rocks, the amount of load transferred through the pile shaft in soils is expected to be small, which has been manifested by full-scale load tests

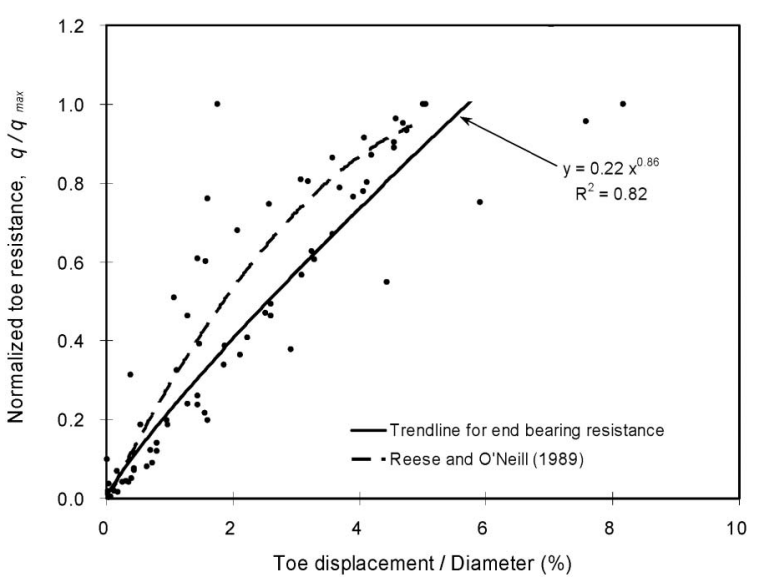

Fig. 4. Load-transfer curves for toe resistance in soils

(e.g., Leung, 1996). From the Hong Kong database, the load taken by the pile shaft in soil is in average $15 \%$ of the applied load. Therefore, the settlement of pile toe due to the load transferred to the soil along the pile shaft is expected to be small and can be neglected in settlement analysis for simplicity. The predicted pile settlement con- 
sists of three components: the elastic pile compression, and the settlements of the toe due to the load transferred along the rock socket and the load transferred to the toe. The settlement due to the load transferred along the rock socket is modelled using a normalized load-transfer curve for rock socket derived from the results of test piles with significant mobilization of the shaft resistance along the rock socket (Fig. 5). While for the settlement due to the load transferred to the rock toe, the load-transfer curve is derived based on the settlement estimation suggested by Timoshenko and Goodier (1970) for a pile founded on bedrock (see Method 3 in Table 2). A homogenous and infinite half space of elastic isotropic rock is assumed. The major parameter in the calculation of $w_{\mathrm{bb}}$ is the rock mass modulus that represents the mass behaviour including the presence of fissures and fractures in the rock mass

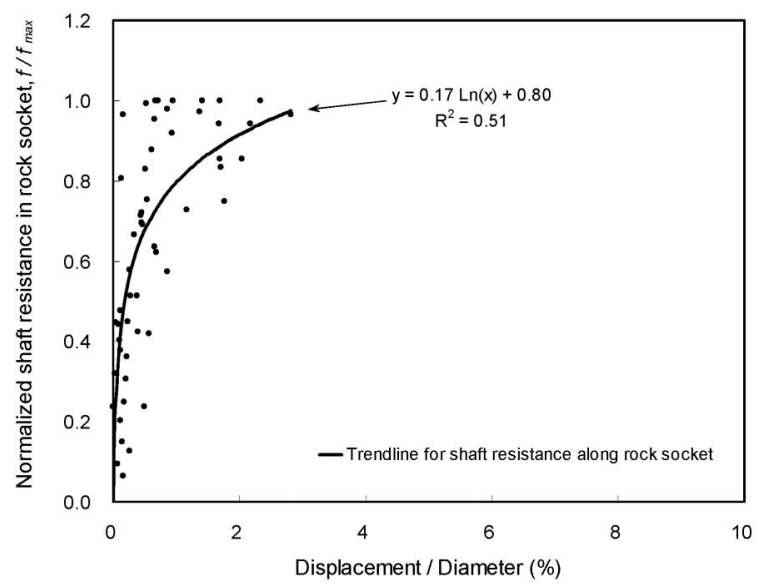

Fig. 5. Shaft load-transfer curves for piles in rock socket under loading. In this study, two methods for estimating the rock deformation modulus are further studied: One based on a correlation with rock quality designation (RQD) (ASTM, 1979), the second based on GEO's correlation (GEO, 2006) with rock mass rating (RMR). An additional correlation between rock deformation modulus and RQD is established in this paper based on Hong Kong data. These three correlations are presented in Table 2 .

To apply the load-transfer method, the ultimate shaft and toe resistances are required. Two design methods for estimating the capacity of the piles in soils are used and the effect of using different design methods for pile capacity prediction on the settlement prediction is studied. The design methods are the $\beta$ method based on Hong Kong data and the empirical correlations with SPT- $N$. For the piles socketed in rocks, the shaft resistance along the rock socket and the toe resistance on rocks are calculated based on correlations with UCS and RQD. The design methods for estimating the total capacity of piles in soil and piles socketed in rocks have been described by Chu (2007) and Zhang and Chu (2009) and are summarized in Table 3 again for easy reference.

\section{EVALUATION OF DESIGN METHODS FOR SETTLEMENT ANALYSIS}

Pile settlement may be calculated using the aforementioned analysis methods and their associated assumptions, such as the load distribution and ultimate resistance components of the piles. In this section, an analysis model together with its associated procedure of determining model parameters are considered as a combination and called a "design method". Four design

Table 3. Design methods for estimating the total capacity of piles in soils and piles in rocks

\begin{tabular}{|c|c|}
\hline Design method & Detailed formulations \\
\hline $\begin{array}{l}\text { Beta method-Hong Kong data } \\
\text { [Method 1-Soil] }\end{array}$ & $\begin{array}{l}\text { Unit shaft resistance }(\mathrm{kPa})=\beta \sigma_{\mathrm{v}}^{\prime} \\
\text { where } \beta=24.96 z^{-1.83} \text { (with liner) } \\
\qquad \begin{array}{l}\beta=21.11 z^{-1.38} \text { (without liner) } \\
\beta=-0.27 \ln z+1.23 \text { (with shaft grouting) } \\
\quad \begin{array}{l}z=\text { depth below ground }(\mathrm{m}) \\
\sigma_{\mathrm{v}}^{\prime}=\text { effective vertical stress }(\mathrm{kPa})\end{array}\end{array} \\
\text { Unit toe resistance }(\mathrm{kPa})=5.26 \sigma_{\mathrm{v}}^{\prime}\end{array}$ \\
\hline $\begin{array}{l}\text { Correlations with SPT- } N \\
\text { (Chu, 2007) } \\
\text { [Method 2-Soil] }\end{array}$ & $\begin{array}{ll}\text { Unit shaft resistance in soil (kPa): } & \\
\text { Fill (without liner) } & f_{\max }=8.78 \bar{N} \\
\text { Alluvium (without liner) } & f_{\max }=4.86 \bar{N} \\
\text { Soil layer with permanent liner } & f_{\max }=3.31 \bar{N}+9.5 \\
\text { Decomposed volcanics } & f_{\max }=0.07 \bar{N}+30.1 \\
\text { Decomposed granites } & f_{\max }=0.33 \bar{N}+58.3 \\
\text { Soil with shaft grouting } & f_{\max }=0.36 \bar{N}+112.0 \\
\text { Unit toe resistance }(\mathrm{kPa}=9.5 \mathrm{~N} & \\
\bar{N}=\text { uncorrected average SPT- } N \text { of a soil layer; } N=\text { uncorrected SPT- } N \text { at the pile toe. }\end{array}$ \\
\hline $\begin{array}{l}\text { Correlations with UCS (in MPa) of rock } \\
\text { (Chu, 2007) } \\
\text { [Method 3-Rock] }\end{array}$ & 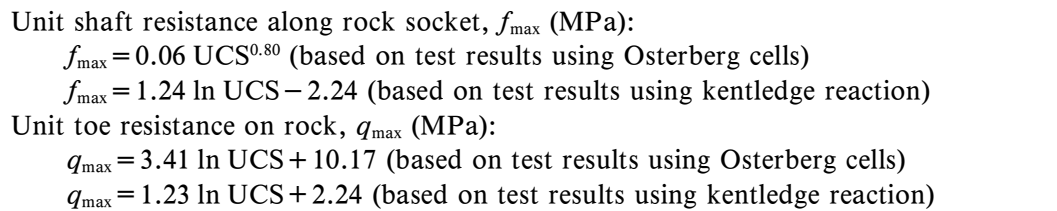 \\
\hline
\end{tabular}



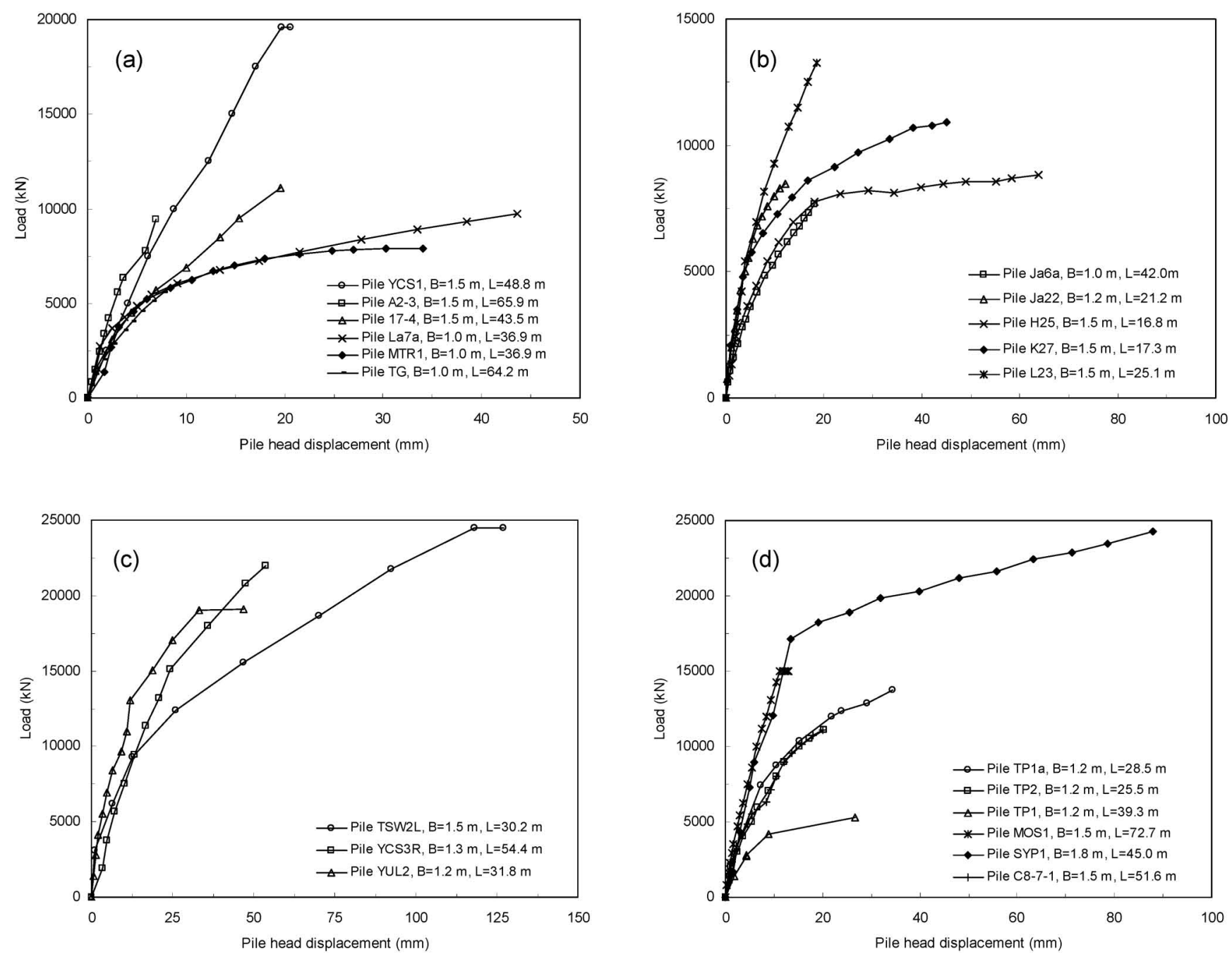

Fig. 6. Load-settlement curves for (a) instrumented piles in soils, (b) for non-instrumented piles in soils, (c) piles with shaft grouting and (d) piles with permanent liner up to saprolites. $B=$ Pile diameter, $L=$ Pile length

methods for piles in soils and three design methods for piles socketed in rocks as shown in Tables 1 and 2, as well as their variations, were evaluated. The calculated pilehead settlement from each "design method" was compared with the measured pile settlement at the working load level. In this study, Buildings Department's failure criterion (BD, 2004) and the Hirany and Kulhaway (1989) criterion were used to define the failure loads and a factor of safety of 2 is applied to define the working load (designated design load) of the pile. The ratio between the measured settlement and the predicted settlement using a particular design method, i.e., the bias factor, measures the degree of deviation of the predicted settlement from the measured settlement. The mean bias factor $\left(\lambda_{\mathrm{S}}\right)$ and the coefficient of variation $\left(\mathrm{COV}_{\mathrm{S}}\right)$ were calculated for each design method.

\section{Piles in Soils}

Figures 6(a)-(d) show the load-settlement curves of 20 piles in soils, which are used to calibrate the performance of the design methods. The figures are grouped according to construction or testing methods [i.e., instrumented piles in Fig. 6(a), non-instrumented piles in Fig. 6(b), use of shaft grouting in Fig. 6(c), and use of permanent liner in Fig. 6(d)]. The predicted load-settlement curves using different design methods for these piles are obtained. As an example, Fig. 7 shows the measured and predicted load-settlement curves for pile SYP. Table 4 presents the first and second moments of the model bias factor at the design load level for the methods in Table 1 and their variations. The predicted settlement values from different design methods are associated with a lower range of $\mathrm{COV}$ at the working load level compared with those of the predicted total pile capacity reported by Chu (2007) and Zhang and Chu (2009). The COV of the design methods for pile capacity analysis ranges from 0.31 to 0.65 , while the COV of pile settlement at the working load level determined based on Davisson's criterion (Davisson, 1972) ranges from 0.22 to 0.58 .

Comparing the design methods, Method 2 (elastic solution) shows a higher accuracy or a lower COV in the prediction than Methods 3 and 4 (load-transfer methods). As suggested by Polous (1989), this is because at the working load level (e.g., approximately 40 to $50 \%$ of the 
ultimate load), the nonlinear property of soils does not have a significant effect on the pile settlement and the elastic solution may be adequate for settlement prediction. At the ultimate load, the nonlinearity of soil behaviour has a strong influence on the load-settlement response; hence the load-transfer analysis can provide a more realistic prediction than the elastic solutions. Moreover, the effects of construction details such as the use of permanent liners and shaft grouting are included in the load-transfer curves when the curves are back calculated from the results of static loading tests.

Comparing Methods $4 \mathrm{a}$ and $4 \mathrm{~b}$ that use different design methods for the estimation of ultimate pile capacity, the one that uses the $\beta$ method based on Hong Kong data shows a lower COV than that based on the empirical correlations with SPT- $N$. This shows that the prediction of pile capacity also introduces uncertainty into the settlement analysis. As summarized in Table 4, the accuracy of the predictions is improved slightly when the construction effects are considered using 48 hours as the reference time between the ends of excavation and concreting. The influence is more evident for Method $4 \mathrm{~b}$. The improved $\mathrm{COV}$ values are comparable to that of Method 4a. Note that the predicted settlement using Method $4 \mathrm{a}$ is rather in-

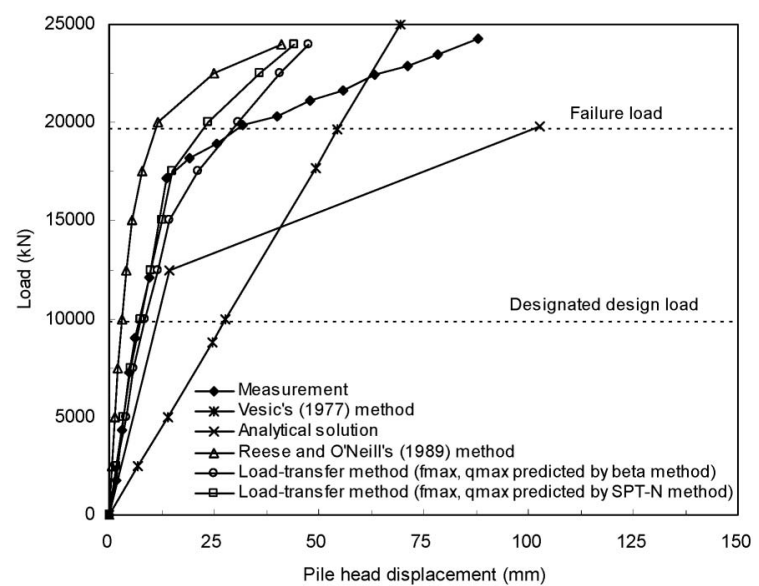

Fig. 7. Load-settlement curves for pile SYP predicted using different analysis models sensitive to the effect of construction time.

\section{Piles in Rocks}

Figures 8(a)-(c) show the load-settlement curves of 15 piles socketed in rocks, which are used to calibrate the performance of the design methods in Table 2. The figures are grouped based on rock type [i.e., granitic rocks in Fig. 8(a), volcanic rocks in Fig. 8(b), and metamorphic rocks in Fig. 8(c)]. In these design methods, the settlement due to the load transferred through the pile shaft embedded in soils is ignored. The predicted settlement consists of the elastic shortening of the pile, the settlement of the base due to the load transferred through the rock socket, and the settlement of the base due to the load transferred to the toe. The load-settlement curves for these piles have been predicted using the three design methods in Table 2. In particular, three different percentages of loads transferred through the rock socket and three methods for estimating the rock mass modulus are considered. Taking pile TMC1 as an example, the measured and predicted load-settlement curves are shown in Fig. 9. The first and second moments of the model bias factor at the design load level for these design methods are summarized in Table 5. The results show that the coefficients of variation for the settlement analysis methods for rock-socketed piles are in general in the vicinity of 0.30 at the working load level, which is encouraging compared with the ability to estimate the capacity of similar bored piles.

The load distribution along depth, which depends on the relative stiffness of the pile shaft and rock socket, may vary with load level. The mobilization of toe resistance on rock is relatively linear to a large toe displacement, similar to Fig. 4 for piles in soils, whereas the rock-socket shaft resistance is mobilized at a small displacement of approximately $1 \% B$ (Fig. 5). When the applied load is low, the stiffness of rock socket is higher than that of the rock toe. Hence, a higher proportion of load is possibly transferred through the rock socket. On the other hand, as the applied load is increased, the stiffness of the rock socket decreases while the stiffness of the rock toe does not change significantly. Consequently, a higher proportion of load is transferred to the rock toe instead of the

Table 4. First and second moments of the model bias factor for settlement of piles in soils at work load level

\begin{tabular}{|c|c|c|c|c|c|c|c|}
\hline \multirow{2}{*}{ Design method } & \multirow{2}{*}{$\begin{array}{c}\text { No. of } \\
\text { cases }\end{array}$} & \multicolumn{3}{|c|}{$\begin{array}{l}\text { Design load based on } \\
\text { Davisson's criterion }\end{array}$} & \multicolumn{3}{|c|}{$\begin{array}{l}\text { Design load based on Hirany and } \\
\text { Kulhawy (1989)'s criterion }\end{array}$} \\
\hline & & $\operatorname{Mean}^{(*)}$ & $\begin{array}{l}\text { Standard } \\
\text { deviation }^{(*)}\end{array}$ & $\operatorname{COV}_{\mathrm{S}}^{(*)}$ & $\operatorname{Mean}^{(*)}$ & $\begin{array}{l}\text { Standard } \\
\text { deviation }^{(*)}\end{array}$ & $\operatorname{COV}_{\mathrm{S}}^{(*)}$ \\
\hline Method 1-Vesic (1977) & 20 & 0.24 & 0.09 & 0.38 & 0.22 & 0.09 & 0.41 \\
\hline $\begin{array}{l}\text { Method 2- } \\
\text { Analytical solution (Mayne and Harris 1993) }\end{array}$ & 12 & 0.64 & 0.14 & 0.22 & 0.65 & 0.22 & 0.34 \\
\hline Method 3-Reese and O’Neill and (1989) & 19 & 1.80 & 0.56 & 0.31 & 1.73 & 0.53 & 0.31 \\
\hline $\begin{array}{l}\text { Method } 4(\mathrm{a})- \\
\text { Load transfer curves using HK beta method }\end{array}$ & 19 & $0.91(0.90)$ & $0.37(0.35)$ & $0.40(0.39)$ & $0.91(0.90)$ & $0.36(0.37)$ & $0.40(0.41)$ \\
\hline $\begin{array}{l}\text { Method } 4(\mathrm{~b})- \\
\text { Load transfer curves using correlations with SPT- } N\end{array}$ & 12 & $1.14(1.05)$ & $0.67(0.43)$ & $0.58(0.41)$ & $1.10(1.07)$ & $0.54(0.46)$ & $0.49(0.43)$ \\
\hline
\end{tabular}

(*) Values in parentheses refer to those when the construction effects are considered at a reference time of 48 hours between the end of excavation and concreting. 

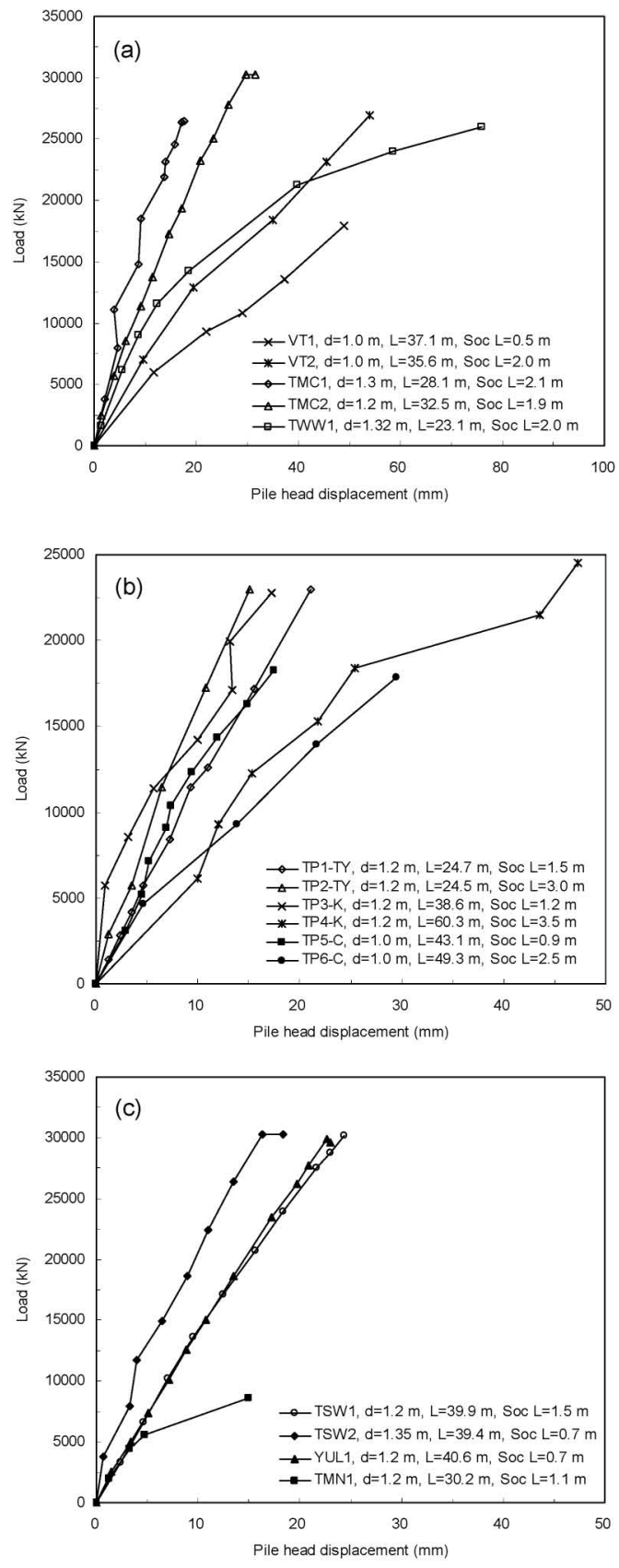

Fig. 8. Load-settlement curves for piles socketed in (a) volcanic rocks, (b) granites and (c) metamorphic rocks. $B=$ Pile diameter, $L=$ Pile length, Soc $L=$ Length of rock socket

rock socket. In Method 1, the percentages of load taken by the pile shaft and pile toe are assumed to be constant values that are obtained based on the average percentage of load transferred to the pile toe at pile failure in the static loading tests. This assumption might lead to underestimation of the load transferred to the rock socket, and may be one reason why the pile settlement at the working load level is generally underestimated (i.e., mean bias $=0.87<1.0$ ) using Method 1 .

Method 2 assumes that all the load is transferred through the rock socket till complete side shear failure occurs. The assumption simulates better the load sharing between the rock socket and the rock toe at a low load

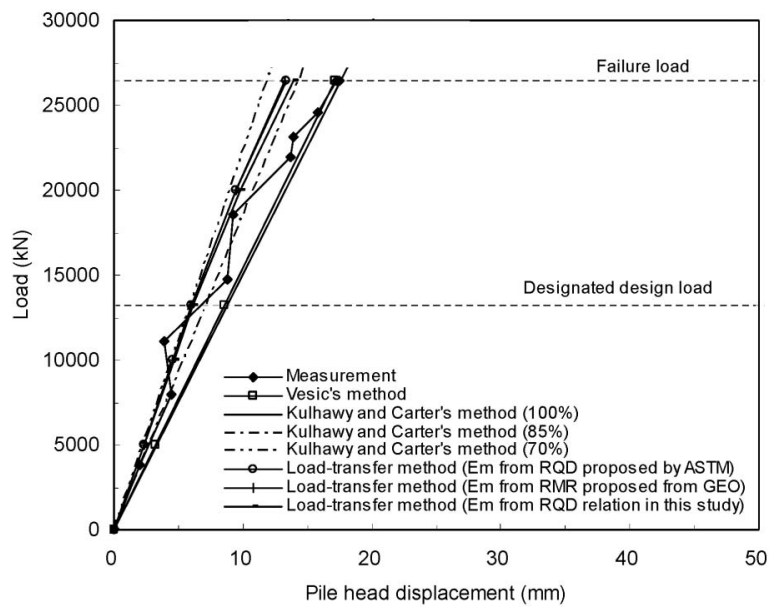

Fig. 9. Load-settlement curves for pile TMC1 predicted using different analysis models

level. The method provides the best estimates of settlement with the mean bias factor close to unity and the lowest COV. However, the percentage of load transferred to the rock socket and rock toe is required in Method 2.

Method 3, the load-transfer method, can simulate the variation of the stiffness of rock socket and rock toe with displacement, and hence provide a more realistic load distribution, particularly at high load levels. Moreover, the percentage of load transferred to the rock socket or the rock toe, which is usually not known, is not required in the method.

RQD is commonly used to estimate the rock mass modulus because RQD is more available than RMR in many cases. From the study, comparing Methods 3(a)-(c), Method 3(c) adopting the correlations with RQD based on Hong Kong data shows higher accuracy or a lower COV of predicted settlement at the working load level. The use of RQD provides an acceptable estimate of rock mass modulus and hence the settlement of a pile on rock. However, RQD is only one of several components of RMR. Other information contained in RMR such as joint conditions and groundwater conditions also affects the rock mass modulus. Therefore, the empirical correlations with RMR can potentially provide a more accurate prediction of rock mass modulus than that based on RQD. In the study, however, the degree of dispersion of Method 3(b) based on RMR is larger, probably due to the limited number of pile cases.

\section{RELIABILITY OF SETTLEMENT ANALYSIS METHODS}

In evaluating the serviceability of foundations, both the estimated settlement and the limiting tolerable settlement are random variables. The uncertainties of estimated settlement using several common design methods for large-diameter bored piles have been quantified using the values of mean bias factor and COV summarized in Tables 4 and 5. The limiting tolerable displacement, 
Table 5. First and second moments of the model bias factor for settlement of piles socketed in rocks at work load level

\begin{tabular}{|c|c|c|c|c|c|c|c|}
\hline \multirow{2}{*}{ Design method } & \multirow{2}{*}{$\begin{array}{l}\text { No. of } \\
\text { cases }\end{array}$} & \multicolumn{3}{|c|}{$\begin{array}{l}\text { Design load based on } \\
\text { Davisson's criterion }\end{array}$} & \multicolumn{3}{|c|}{$\begin{array}{l}\text { Design load based on Hirany and } \\
\text { Kulhawy (1989)'s criterion }\end{array}$} \\
\hline & & Mean & $\begin{array}{l}\text { Standard } \\
\text { deviation }\end{array}$ & $\mathrm{COV}_{\mathrm{s}}$ & Mean & $\begin{array}{l}\text { Standard } \\
\text { deviation }\end{array}$ & $\mathrm{COV}_{\mathrm{S}}$ \\
\hline Method 1-Vesic (1977) & 14 & 0.87 & 0.27 & 0.30 & 0.90 & 0.34 & 0.38 \\
\hline Method 2(a)-Kulhawy and Carter (1992) [ 100\%] & 14 & 0.81 & 0.19 & 0.24 & 0.83 & 0.21 & 0.26 \\
\hline Method 2(b)-Kulhawy and Carter (1992) [ 85\%] & 14 & 1.01 & 0.24 & 0.24 & 1.03 & 0.27 & 0.26 \\
\hline Method 2(c)-Kulhawy and Carter (1992) [ 70\%] & 14 & 1.22 & 0.41 & 0.34 & 1.20 & 0.33 & 0.28 \\
\hline $\begin{array}{l}\text { Method } 3(\mathrm{a})- \\
\text { Load transfer method using the ASTM correlation }\end{array}$ & 14 & 1.21 & 0.36 & 0.30 & 1.24 & 0.42 & 0.34 \\
\hline $\begin{array}{l}\text { Method 3(b)- } \\
\text { Load transfer method using correlation with RMR }\end{array}$ & 5 & 0.57 & 0.35 & 0.61 & 0.51 & 0.34 & 0.66 \\
\hline $\begin{array}{l}\text { Method 3(c)- } \\
\text { Load transfer method using correlation with RQD }\end{array}$ & 14 & 1.11 & 0.33 & 0.30 & 1.12 & 0.36 & 0.32 \\
\hline
\end{tabular}

which represents the performance of the whole foundation system, is affected by many factors, such as the type and size of the structure, substructure-superstructure interactions, the properties of the structural materials and the subsurface soils, and the rate and uniformity of settlement (Wahls, 1981; Burland et al., 2001; Zhang and $\mathrm{Ng}$, 2005). The distributions of limiting tolerable settlement for several categories of buildings and bridges have been established based on observed performance of the superstructures (Zhang and Ng, 2005, 2007).

The reliability of piles in terms of settlement can be evaluated in a similar way to that for the ultimate limit state. The performance function for SLS is shown in Eq. (1) in terms of the estimated foundation system settlement $\left(S_{\text {ef }}\right)$ and the limiting tolerable settlement of the superstructure $\left(S_{\mathrm{t}}\right)$. However, the settlement calibration is conducted for single piles only in the earlier sections, whereas $S_{\mathrm{t}}$ is for a foundation system. The settlement of the foundation system, rather than the single pile $\left(S_{\mathrm{e}}\right)$, should be compared with $S_{\mathrm{t}}$. The relationship among the settlements of a single pile, a pile group, and a pile foundation system has been explored by $\mathrm{Xu}$ et al. (2007). To calculate the foundation system settlement, a group settlement ratio $\left(R_{\mathrm{g}}\right)$ and a system settlement ratio $\left(R_{\mathrm{s}}\right)$ are applied to the single pile settlement:

$$
S_{\mathrm{ef}}=R_{\mathrm{g}} R_{\mathrm{s}} S_{\mathrm{e}}
$$

where $R_{\mathrm{g}}=$ ratio of the settlement of a pile group to that of a single pile at the same average design load per pile and $R_{\mathrm{s}}=$ ratio of the settlement of a pile system to that of a pile group under the same average design load per pile. O'Neill (1983) and Xu and Zhang (2007) studied the settlement ratio of driven and bored pile groups. $R_{\mathrm{g}}$ is found to decrease with the load level whereas the COV of $R_{\mathrm{g}}$ is found to increase with the load level. Based on field test results collected by O'Neill (1983), a $R_{\mathrm{g}}$ value of 1.75 is taken for larger-diameter bored piles at the work load level. $R_{\mathrm{s}}$ is related to deep soil properties and influences from the superstructure (Xu et al., 2007). Very little measurement information on $R_{\mathrm{s}}$ is available in the literature. In this paper, $R_{\mathrm{s}}$ is assumed to be 1.0 due to the lack of information.

Ignoring the variability in $R_{\mathrm{g}}$ and $R_{\mathrm{s}}$, the variability in
$S_{\text {ef }}$ can be described by the variability in $S_{\text {e }}$ following Eq. (2). Zhang and $\mathrm{Ng}$ (2005) showed, using a log-normal probability graph, that $S_{\mathrm{t}}$ follows a log-normal distribution. Zhang et al. (2008) also demonstrated through the chi-square goodness-of-fit test that the frequency diagrams for estimated pile settlement could be described by a log-normal distribution at a significance level of $5 \%$. Given values of the mean and COV of $S_{\mathrm{t}}$ and $S_{\mathrm{e}}$, the serviceability reliability index $\left(I_{\mathrm{R}_{\mathrm{S}}}\right)$ in terms of settlement can be calculated using the first order, second moment method (e.g., Zhang and Phoon, 2006),

$$
\begin{aligned}
I_{\mathrm{R}_{\mathrm{s}}} & =\frac{\ln \left(\frac{\bar{S}_{\mathrm{t}}}{\bar{S}_{\mathrm{e}} R_{\mathrm{g}} R_{\mathrm{s}}} \sqrt{\frac{1+\mathrm{COV}_{\mathrm{e}}^{2}}{1+\mathrm{COV}_{\mathrm{t}}^{2}}}\right)}{\sqrt{\ln \left[\left(1+\mathrm{COV}_{\mathrm{e}}^{2}\right)\left(1+\mathrm{COV}_{\mathrm{t}}^{2}\right)\right]}} \\
= & \frac{\ln \left(\frac{\bar{S}_{\mathrm{t}} \lambda_{\mathrm{s}}}{\bar{S}_{\mathrm{m}} R_{\mathrm{g}} R_{\mathrm{s}}} \sqrt{\left.\frac{1+\mathrm{COV}_{\mathrm{e}}^{2}}{1+\mathrm{COV}_{\mathrm{t}}^{2}}\right)}\right.}{\sqrt{\ln \left[\left(1+\mathrm{COV}_{\mathrm{e}}^{2}\right)\left(1+\mathrm{COV}_{\mathrm{t}}^{2}\right)\right]}}
\end{aligned}
$$

where $\bar{S}_{\mathrm{t}}=$ mean of the limiting tolerable settlement; $\bar{S}_{\mathrm{m}}=$ mean of the measured settlement; $\bar{S}_{\mathrm{e}}=$ mean of the estimated settlement using a design method $\left(\bar{S}_{\mathrm{m}}=\lambda_{\mathrm{s}} \bar{S}_{\mathrm{e}}\right) ; \lambda_{\mathrm{s}}=$ mean of the model bias factor; $\mathrm{COV}_{\mathrm{t}}$ and $\mathrm{COV}_{\mathrm{e}}=$ coefficients of variation of $S_{\mathrm{t}}$ and $S_{\mathrm{e}}$, respectively.

The statistics of the model bias factor $\left(\lambda_{\mathrm{s}}\right.$ and $\left.\mathrm{COV}_{\mathrm{e}}\right)$ for the design methods calibrated in this paper have been summarized in Tables 4 and 5. Zhang and Ng (2005) investigated 52 cases of buildings supported on deep foundations. The majority of the buildings were concreteframe office or residential structures. The limiting tolerable displacements of these buildings were determined through an analysis of observed building performance using fragility curves. The mean and standard deviation of vertical limiting tolerable displacement were found to be $96 \mathrm{~mm}$ and $56 \mathrm{~mm}$, respectively. These limiting tolerable displacement statistics are used to illustrate the reliability calculation here. Tables 6 and 7 show the calculated values of reliability index for piles in soils and piles socketed in rocks, respectively. The reliability of the piles in soils is generally higher than that of the piles socketed in rocks. Excluding the results from Vesic's method for the piles in soils and the load-transfer method using a correlation with RMR for the piles in rocks, the reliability in- 
Table 6. Serviceability reliability index for piles in soils

\begin{tabular}{lcc}
\hline \multicolumn{1}{c}{ Design method } & \multicolumn{2}{c}{ Serviceability reliability index $\left.I_{\mathrm{R}_{\mathrm{s}}}{ }^{*}\right)$} \\
\cline { 2 - 3 } & $\begin{array}{c}\text { Design load based on } \\
\text { Davisson's criterion }\end{array}$ & $\begin{array}{c}\text { Design load based on Hirany and } \\
\text { Kulhawy (1989)'s criterion }\end{array}$ \\
\hline Method 1-Vesic (1977) & 1.17 & 1.40 \\
Method 2-Analytical solution & 2.91 & 3.11 \\
Method 3-Reese and O'Neill (1989) & 4.43 & 4.75 \\
Method 4-Load transfer curves using the HK beta method & $3.20(3.16)$ & $3.52(3.49)$ \\
Method 5-Load transfer method using correlations with SPT- $N$ & $3.13(3.35)$ & $3.58(3.67)$ \\
\hline
\end{tabular}

(*) Values in parentheses refer to those when the construction effects are considered at a reference time of 48 hours between the end of excavation and concreting.

Table 7. Serviceability reliability index for piles socketed in rocks

\begin{tabular}{lcc}
\hline \multicolumn{1}{c}{ Design method } & \multicolumn{2}{c}{ Serviceability reliability index $I_{\mathrm{R}_{\mathrm{s}}}$} \\
\cline { 2 - 3 } & $\begin{array}{c}\text { Design load based on } \\
\text { Davisson's criterion }\end{array}$ & $\begin{array}{c}\text { Design load based on Hirany and } \\
\text { Kulhawy (1989)'s criterion }\end{array}$ \\
\hline Method 1-Vesic's (1977) & 2.54 & 2.48 \\
Method 2(a)-Kulhway and Cater (1992) [100\%] & 2.51 & 2.51 \\
Method 2(b)-Kulhway and Cater (1992) [85\%] & 2.87 & 2.87 \\
Method 2(c)-Kulhway and Cater (1992) [70\%] & 3.02 & 3.11 \\
Method 3(a)-Load transfer method using the ASTM correlation & 3.08 & 3.05 \\
Method 3(b)-Load transfer method using correlation with RMR & 1.61 & 1.43 \\
Method 3(c)-Load transfer method using correlation with RQD & 2.93 & 2.93 \\
\hline
\end{tabular}

dex values are in the ranges of 3.11-4.75 for the piles in soils, and 2.48-3.11 for the piles socketed in rocks at the work load level defined using the Hirany and Kulhawy failure criterion. The reliability level is, in average, improved when the construction time effects are considered.

\section{CONCLUSIONS}

Several common design methods for predicting the settlement of large-diameter bored piles are calibrated at the working load level against results of 36 cases of static loading tests on large-diameter bored piles in Hong Kong for the purpose of developing limit state design codes. Load-transfer curves for representing the mobilization of the shaft and toe resistances of large-diameter bored piles are suggested based on Hong Kong data and settlement analysis using such load-transfer curves is also calibrated. Based on the above studies, the following conclusions can be drawn:

1. For piles in soils, the predicted settlement values based on different design methods are associated with a lower range of $\mathrm{COV}$ between 0.22 and 0.58 at the working load level compared with those of the predicted total pile capacity.

2. The COV values of the model bias factor for the design methods for piles socketed in rocks are generally smaller than 0.30, which is encouraging compared with the ability to estimate the capacity of bored piles socketed in rocks.

3. Excluding the results from Vesic's method for piles in soils and the load-transfer method using a correlation with RMR for piles in rocks, the reliability index values are $I_{\mathrm{R}_{\mathrm{S}}}=3.11-4.75$ for the piles in soils, and $I_{\mathrm{R}_{\mathrm{S}}}$ $=2.48-3.11$ for the piles socketed in rocks at the work load level defined using the Hirany and Kulhawy failure criterion.

4. The load-transfer methods based on Hong Kong data are associated with appropriate model bias factors close to unity and acceptable reliability levels of $I_{\mathrm{R}_{\mathrm{s}}}=$ 2.93-3.58.

5. The reliability of the load-transfer method using correlations with SPT- $N$ for piles in soils is improved when the construction effects are considered using 48 hours as the reference time between the ends of excavation and concreting.

\section{ACKNOWLEDGEMENT}

The work reported in this paper was substantially supported by the Research Grants Council of the Hong Kong SAR (Project HKUST6126/03E).

\section{REFERENCES}

1) ASTM (1979): Standard Method of Test for Triaxial Compressive Strength of Undrained Rock Core Specimens without Pore Pressure Measurements, American Society of Testing and Materials, ASTM Designation D 2664-67, Annual book of ASTM Standards, 19, 632 .

2) Buildings Department (2004): Code of Practice for Foundations, Buildings Department, Hong Kong.

3) Burland, J. B., Standing, J. R. and Jardine, F. M. (2001): Assessing the risk of building damage due to tunnelling: lessons from the Jubilee line extension, London, Proc. 14th Southeast Asian Geotechnical Conference, Hong Kong, 17-44. 
4) Chu, L. F. (2007): Calibration of Design Methods for LargeDiameter Bored Piles for Limit State Design Code Development, MPhil Thesis, the Hong Kong University of Science and Technology, Hong Kong.

5) Coyle, H. M. and Reese, L. C. (1966): Load transfer for axially loaded piles in clay, Journal of the Soil Mechanics and Foundation Division, ASCE, 92 (SM2), 1-26.

6) Davisson, M. T. (1972): High capacity piles, Proc. ASCE Lecture Series, Innovations in Foundation Construction, ASCE, New York.

7) Geotechnical Engineering Office (GEO) (2006): Foundation Design and Construction, GEO Publication No. 1/2006, Geotechnical Engineering Office, Hong Kong.

8) Hirany, A. and Kulhawy, F. H. (1989): Interpretation of load tests on drilled shafts, Foundation Engineering: Current Principles and Practices (ed. by F. H. Kulhaway), ASCE, New York, 2, 1132-1149.

9) Kulhawy, F. H. and Carter, J. P. (1992): Socketed foundation in rock masses, Engineering in Rock Masses (ed. by F. H. Bell), Butterworth-Heinemann, Oxford, 509-529.

10) Leung, C. F. (1996): Case studies of rock-socketed piles, Geo technical Engineering Journal, Southeast Asian Geotechnical Society, 27(1), 51-67.

11) Mayne, P. W. and Harris, D. E. (1993): Axial Load-Displacement Behaviour of Drill Shaft Foundations in Piedmont Residuum, FHWA Publication No. 41-30-3175, Georgia Institute of Technology, Atlanta.

12) O’Neill, M. W. (1983): Group action in offshore piles, Geotechnical Practice in Offshore Engineering (ed. by S. G. Wright), ASCE, New York.

13) O’Neill, M. W. and Reese, L. C. (1999): Drilled Shafts: Construction Procedures and Design, Report FHWA-IF-99-025, Federal Highway Administration, McLean, Virginia.

14) Poulos, H. G. (1989): Pile behaviour-theory and application, Geotechnique, 39(3), 365-415.

15) Randolph, M. F. and Wroth, C. P. (1978): Analysis of deformation of vertically loaded piles, Journal of Geotechnical Engineering Division, ASCE, 104(12), 1465-1488.
16) Reese, L. C. and O'Neill, M. W. (1989): New design method for drilled shaft from common soil and rock tests, Foundation Engineering: Current Principles and Practices (ed. by F. H. Kulhaway), ASCE, New York, 2, 1026-1039.

17) Timoshenko, S. P. and Goodier, J. N. (1970): Theory of Elasticity, McGraw-Hill, New York.

18) Vesic, A. S. (1977): Design of Pile Foundation, National Cooperative Highway Research Program Synthesis of Practice No. 42, Transportation Research Board, Washington, D.C.

19) Wahls, H. E. (1981): Tolerable settlement of buildings, Journal of Geotechnical Engineering, ASCE, 107(11), 1489-1504.

20) $\mathrm{Xu}, \mathrm{Y}$. and Zhang, L. M. (2007): Settlement ratio of pile groups in sandy soils from filed load tests, Journal of Geotechnical and Geoenvironmental Engineering, ASCE, 133(8), 1048-1054.

21) Xu, Y., Zhang, L. M. and Dasaka, M. (2007): Serviceability analysis: from single pile to pile group and pile system, Proc. ICASP'10 (ed. by J. Kanda, T. Takada, H. Furuta), Tokyo, August 2007, Taylor \& Francis, in CD Rom.

22) Zhang, L. M. and Chu, L. F. (2009): Calibration of methods for designing large-diameter bored piles: Ultimate limit state, Soils and Foundations, 49(6), 883-895.

23) Zhang, L. M. and Ng, M. Y. (2005): Probabilistic limiting tolerable displacements for serviceability limit state design of foundations, Geotechnique, 55(2), 151-161.

24) Zhang, L. M. and Ng, M. Y. (2007): Limiting tolerable settlement and angular distortion for building foundations, Geotechnical Special Publication No. 170, Probabilistic Applications in Geotechnical Engineering (ed. by K. K. Phoon, G. A. Fenton, E. F. Glynn, C. H. Juang, D. V. Griffiths, T. F. Wolff and L. M. Zhang), ASCE, Reston, in CD ROM.

25) Zhang, L. M. and Phoon, K. K. (2006): Serviceability considerations in reliability-based foundation design, Geotechnical Special Publication No. 153, Foundation Analysis and Design-Innovative Methods (ed. by R. L. Parsons, L. M. Zhang, W. D. Guo, K. K. Phoon, and M. Yang), ASCE, Reston, 127-136.

26) Zhang, L. M., Xu, Y. and Tang, W. H. (2008): Calibration of models for pile settlement analysis using 64 field load tests, Canadian Geotechnical Journal, 45(1), 59-73. 